\title{
ANTIHYPERGLYCEMIC ACTIVITIES OF ULI BANANA LEAVES ON ORAL SUGAR TOLERANCE
}

Phebe Hendra*

Nona Rizki

Elin Nidia Safitri
Department of Pharmacology and Clinical Pharmacy, Faculty of Pharmacy, Sanata Dharma University, Jogjakarta, 55282, Indonesia

\section{ABSTRACT}

Banana has been widely cultivated. This study aimed to determine the antihyperglycemic activity of Uli banana leaves infusion. The antihyperglycemic activity was evaluated by oral glucose and sucrose tolerance test. A bolus of sugar was given after Uli banana leaves infusion and blood was sampled at $0,15,30,60,90$ and 120 minutes for glucose analyses. The trapezoidal rule was used to determine the area under the curve (AUC) blood glucose. Infusion of Uli banana leaves $3.3 \mathrm{~g} / \mathrm{kg}$ showed a significant decrease AUC $(\mathrm{p}<0.05)$ in the glucose tolerance test, while that of dose $0.8 \mathrm{~g} / \mathrm{kg}$ reduced significantly $(\mathrm{p}<0.05)$ in the sucrose tolerance test. The results showed that Uli banana leaves infusion possesses antihyperglycemic effect in mice.

Keywords: Antihyperglycemic, glucose, leaves; sucrose, uli banana

\section{ABSTRAK}

Buah pisang telah dibudidayakan secara luas. Penelitian ini bertujuan untuk mengetahui aktivitas antihiperglikemik dari infusa daun pisang Uli. Uji aktivitas antihiperglikemik dievaluasi dengan menggunakan uji toleransi glukosa dan sukrosa oral. Bolus gula diberikan setelah infusa daun pisang Uli dan dilakukan sampling darah pada menit ke-0, 15, 30, 60, 90 dan 120 untuk dilakukan analisis glukosa darah. Nilai Area under the Curve (AUC) glukosa darah dihitungkan menggunakan metode trapezoid. Infusa daun pisang Uli dosis $3,3 \mathrm{~g} / \mathrm{kg}$ menunjukkan penurunan AUC signifikan $(\mathrm{p}<0,05)$ pada uji toleransi glukosa, sedangkan dosis $0,8 \mathrm{~g} / \mathrm{kg}$ memberikan penurunan AUC signifikan $(\mathrm{p}<0,05)$ pada uji toleransi sukrosa. Hasil penelitian menunjukkan bahwa infusa daun pisang Uli mempunyai efek antihiperglikemik pada mencit.

Kata kunci: Antihiperglikemik, daun, glukosa, pisang uli, sukrosa

\section{Article Information}

Article Type: Short Communications and Notes

Journal Type: Open Access

Volume: 2 Issue 2

Manuscript ID v2n2519-1

Received Date

17 November 2020

Accepted Date

4 February 2021

Published Date

17 February 2021

DOI: $10.33555 /$ jffn.v2i2.59

Corresponding author: Phebe Hendra

Jogjakarta, Indonesia, 55282

Email: phebe_hendra@usd.ac.id

Citation:

Hendra, P., Rizki, N., Safitri, E.N. 2021. Antihyperglycemic activities of Uli banana leaves on oral sugar tolerance. J. Functional Nutraceutical, 2(2), pp.75-79

Copyright: ๑2021 Swiss German University. This is an open-access article distributed under the terms of the Creative Commons Attribution 4.0 Internation License, which permits unrestricted use, distribution and reproduction in any medium, provided the original author and source are credited. 


\section{INTRODUCTION}

The usage of traditional medicine and medicinal plants to maintain health is widely applied in developing countries. Therefore, efforts are needed to properly identify and recognize the importance of medicinal plants to implement these strategies (Sofowora et al., 2013).

The use of natural antioxidants provides an alternative prevention strategy as well as to treat many chronic and degenerative diseases. Banana, a member of family Musaceae, is a tree cultivated in many tropical regions around the world, including in Indonesia. The total number of cultivars of bananas has been estimated to be around 300 to more than 1,000 . Various parts of banana, such as fruits, peel, leaves, roots, and pseudostem have shown their medicinal potential, like antiulcerogenic, antioxidant, antimicrobial, antipyretic, and antihyperglycemic activities (Karadi et al., 2011; Pannangpetch et al., 2001; Eleazu et al., 2010; Maya et al., 2015; Kappel et al., 2013). Based on these findings, we designed the present study with an objective to evaluate antihyperglycemic activity of Uli banana leaves (Musa paradisiaca L. Uli) infusion in glucose tolerance by using oral sugar tolerance test.

\section{MATERIALS AND METHOD}

\section{Materials}

Fresh Uli banana leaves were collected in the same season and from the same area in Kebun Plasma Nutfah Pisang Yogyakarta. Glucose and sucrose were acquired from Merck Millipore, Germany. Male mice (weight $18-23 \mathrm{~g}$; age, 8 to 10 week) were purchased from the Imono Laboratory, Sanata Dharma University, Indonesia. Animals were acclimated for one week before experiments and kept in the housing facilities. They were fed standard pelleted diet and drink ad libitum and maintained at $22 \pm 2{ }^{\circ} \mathrm{C}$ with a fixed $12 \mathrm{~h}$ artificial light period. The study protocol was approved by the Medical and Health Research Ethics Committee Faculty of Medicine Gadjah Mada University-Dr. Sardjito General Hospital Yogyakarta Indonesia with approval number KE/FK/0510/EC/2019 and KE/FK/0833/EC/2019.

\section{Preparation of infusion of Uli banana leaves (IBU)}

Collected Uli banana leaves were washed and minced to pieces at $\pm 2 \mathrm{~mm}$ thickness. The leaves were dried using an oven at $50{ }^{\circ} \mathrm{C}$ and powdered using a powdering machine and sifted using a sieve with mesh number 50. Ten grams of Uli banana leaves were weighed and added with $100 \mathrm{~mL}$ of distilled water, which then heated over a water bath at $90{ }^{\circ} \mathrm{C}$ for 15 minutes.

\section{Oral glucose tolerance test}

Test animals fasted overnight. Mice were randomly divided into 5 groups ( $n=5 /$ group) and received treatment orally: Group I was control group. Group II was given $2 \mathrm{~g} / \mathrm{kg}$ glucose solution (Rathod et al., 2011; Ali et al., 2013; Wahyuningsih et al., 2018; Gunawan-Puteri, et al., 2018). Group III-V was given IBU dose of $0.8,1.67,3.3 \mathrm{~g} / \mathrm{kg}$. Thirty minutes after IBU administration, all mice group III-V were consecutively given glucose solution (Yusoff et al., 2015; Pattanayak et al., 2009; James et al., 2009; Gunawan-Puteri et al., 2018). Blood was collected from the lateral tail vein, and blood glucose was measured using GlucoDr®auto glucometer (All Medicus Co. Ltd) at 0 (before treatment), 15, 30, 60, 90 and $120 \mathrm{~min}$ after the sugar challenge (Wulandari, 2016; Yeo et al., 2011). The trapezoidal rule was used to determine the area under the curve (AUC) blood glucose (Wongnawa et al., 2014; Eyesin et al., 2010; Jo et al., 2011; Fransisca et al., 2018).

\section{Oral sucrose tolerance test (OSucTT)}

Overnight-fasted mice rats were divided into 4 groups and the procedure mentioned in Oral Glucose Tolerance Test was applied to a similar set of animals of group II-V. However, sucrose, at a dose of $4 \mathrm{~g} / \mathrm{kg} \mathrm{B.W}$. was administered in place of glucose (Ali et al. 2013, Gunawan-Puteri et al., 2018; Fransisca et al., 2018).

\section{Statistical analysis}

Statistical significance was evaluated using SPSS 22 software with variance (ANOVA) and subsequently by Scheffe test. A p-value $<0.05$ was considered statistically significant. 


\section{RESULTS AND DISCUSSION}

This study evaluated the antihyperglycemic activity of IBU in glucose tolerance by using oral sugar tolerance test. The oral sugar tolerance model is a widely used experimental procedure for metabolic studies in mice. Glucose and sucrose are the most commonly consumed sugars. Excessive consumption of sugar stimulates type 2 diabetes mellitus, which is associated with obesity and insulin resistance. In this present study, the postprandial blood glucose levels will increase after glucose or sucrose was given. The AUCs of glucose levels of mice given both glucose and sucrose were significantly higher $(\mathrm{p}<0.05)$ than that of control mice, 1316.18 and 1309.36 vs 1020.98 mmol.min/L, respectively. Sakamoto et al. (2012) reported hyperglycemia in the early phase after oral glucose administration in mice, and the abnormal glucose metabolism in the liver can cause glucose intolerance observed in the mice.

Tabel 1 shows the effect of Uli banana leaves after oral glucose administration on mice. The administration IBU $3.3 \mathrm{~g} / \mathrm{kg}$ showed a smaller AUC area and was statistically significant compared to glucose group $(\mathrm{p}<0.05)$. IBU 0.8 and $1.67 \mathrm{~g} / \mathrm{kg}$ failed to exert any reduction on the tolerance level following oral glucose loading. Results of the glucose tolerance test revealed that IBU dose $3.3 \mathrm{~g} / \mathrm{kg}$ was the most effective in lowering AUCs of glucose levels in mice (121.7\%), whereas IBU 0.88 and $1.67 \mathrm{~g} / \mathrm{kg}$ did not exhibit any significant antihyperglycemic effect in mice.

As shown in Table 2, IBU $0.8 \mathrm{~g} / \mathrm{kg}$ of IBU caused a significant reduction in AUCs glucose levels compared to sucrose group $(\mathrm{p}<0,05)$. On the other hand, IBU 1.67 and $3.3 \mathrm{~g} / \mathrm{kg}$ did not show significant differences, when compared to sucrose group.

Although, in this study, we provided evidence that IBU had antihyperglycemic activity, significant difference effect of IBU was found between glucose and sucrose administration. Considering that glucose as monosaccharide and sucrose as disaccharide, it could be speculated that the action mechanism of IBU is different from that of sugar.
The exact potency of IBU on postprandial hyperglycemia in a mice model is not yet clear and the potential antihyperglycemic component remains to be investigated.

Table 1. Percentage of reduction of AUC of Uli banana leaves after oral glucose administration on mice

\begin{tabular}{lcc}
\hline \multicolumn{1}{c}{ Treatment } & AUC $(\mathrm{mmol} . \mathrm{min} / \mathrm{L})$ & $\%$ reduction of AUC \\
\hline Control & $1020.98 \pm 176.64^{\mathrm{b}}$ & - \\
Glucose & $1316.18 \pm 176.64^{\mathrm{a}}$ & - \\
IBU 0.8 g/kg + glucose & $1243.51 \pm 71.46$ & 24.6 \\
IBU $1.67 \mathrm{~g} / \mathrm{kg}+$ glucose & $1355.31 \pm 56.12^{\mathrm{a}}$ & -13.3 \\
IBU $3.3 \mathrm{~g} / \mathrm{kg}+$ glucose & $957.05 \pm 74.36^{\mathrm{b}}$ & 121.7
\end{tabular}

Values are expressed as mean \pm SD of five animals in each group. a: $p<0.05$ vs control; b: $p<0.05$ vs glucose. IBU: infusion of Uli banana leaves.

Table 2. Percentage of reduction of AUC of Uli banana leaves after oral sucrose administration on mice

\begin{tabular}{lcc}
\hline \multicolumn{1}{c}{ Treatment } & AUC $(\mathrm{mmol} . \mathrm{min} / \mathrm{L})$ & \% reduction of AUC \\
\hline Control & $1020.98 \pm 176.64^{\mathrm{b}}$ & - \\
Sucrose & $1309.36 \pm 92.72^{\mathrm{a}}$ & - \\
IBU 0.8 g/kg + sucrose & $1090.50 \pm 89.33^{\mathrm{b}}$ & 75.9 \\
IBU $1.67 \mathrm{~g} / \mathrm{kg}+$ sucrose & $1210.54 \pm 120.76$ & 34.3 \\
IBU 3.3 g/kg + sucrose & $1235.27 \pm 105.60$ & 25.7 \\
\hline
\end{tabular}

Values are expressed as mean \pm SD of five animals in each group. a: $p<0.05$ vs control; b: $p<0.05$ vs sucrose. IBU: infusion of Uli banana leaves.

These results may demonstrate the positive effect of oral administration of Uli banana leaves infusion (IBU) against hyperglycemia resulting in sugar tolerance test. Hypoglycemic and/or antihyperglycemic activity of banana have been reported by some references. Kappel et al. (2013) reported the significant antihyperglycemic effect of banana leaves on the regulation of glucose homeostasis. More recently, Adewoye \& Ige (2016) demonstrated that the methanol extract of banana leaves has hypoglycemic properties in alloxan-induced diabetic rats. Beidokhti \& Jäger, (2017) reported the hypoglycemic effects of banana due to their natural ability of pancreatic $\beta$-cells for insulin secretion, or bioactive compounds such as flavonoids, alkaloids and anthocyanins, which act as insulin-like molecules or insulin secretagogues. Based on previous study, the antihyperglycemic 
activity of IBU might be occurs through inhibition of insulin secretion. Further molecular research is needed to find out the mechanisms of active components contained in banana leaves.

\section{CONCLUSION}

Infusion of Uli banana leaves $3.3 \mathrm{~g} / \mathrm{kg}$ showed an $121.7 \%$ reduction in AUC glucose levels in the glucose tolerance test, while a $75.9 \%$ reduction of dose $0.8 \mathrm{~g} / \mathrm{kg}$ in the sucrose tolerance test. Overall, these results show that Uli banana leaves infusion possesses antihyperglycemic activity in glucose tolerance by using oral sugar tolerance test. These pharmacological activities provide pharmacological evidence of the potential use of banana leaves as an antihyperglycemic agent. Therefore, IBU can be developed to prevent diabetes through controlling insulin secretion which can further control blood glucose levels.

\section{ACKNOWLEDGEMENT}

This study was financed by a grant from LPPM USD (Letter No. 019/Penel./LPPM-USD/III/2018) and Faculty of Pharmacy USD annual budget year 2019.

\section{REFERENCES}

Adewoye, E.O., Ige, A.O. 2016. Lipid profile and electrolyte composition in diabetic rats treated with leaf extract of Musa sapientum. Journal of Dietary Supplements. 13(1), pp.106-117.

Ali, R.B., Atangwho, I.J., Kuar, N., Ahmad, M., Mahmud, R., Asmawi, M.Z. 2013. In vitro and in vivo effects of standardized extract and fractions of Phaleria macrocarpa fruits pericarp on lead carbohydrate digesting enzymes. BMC Complementary and Alternative Medicine. 13(39), pp.1-11.

Beidokhti, M.N., Jäger, A.K. 2017. Review of antidiabetic fruits, vegetables, beverages, oils and spices commonly consumed in the diet. Journal of Ethnopharmacology. 201, pp.2641.

Eleazu, C.O., Okafor, P.N., Ahamefuna, I. 2010. Total antioxidant capacity, nutritional composition and inhibitory activity of unripe plantain (Musa paradisiacae) on oxidative stress in alloxan induced diabetic rabbits. Pakistan Journal of Nutrition. 9, pp.10521057.

Eyesin, O., Ebong, P., Eyong, E., Awofisayo, O., Agboke, A. 2010. Effect of Telfairia occidentalis on oral glucose tolerance in rats. African Journal of Pharmacy and Pharmacology.4(6), pp.368-372.

Fransisca, Kalangi, G.E., Saptasari, D.C., Hendra. P. 2018. The effect of pasak bumi roots towards blood glucose level in glucose-loaded mice. Journal of Pharmaceutical Sciences and Community. 15(1), pp.1-6.

Gunawan-Puteri, M. D. P. T., Rustandi, F., Hendra, P. 2018. Spray dried aqueous extract of lemongrass (Cymbopogon citratus) exhibits in vitro and in vivo anti hyperglycemic activities. Journal of Pharmaceutical Sciences and Community. 15(2), pp.55-61.

James, D.B., Owolabi, O., Elebo, N., Hassan, S., Odemene, L. 2009. Glucose tolerance test and some biochemical effect of Phyllanthus amarus aquoeus extacts on normaglycemic albino rats. African Journal of Biotechnology. 8(8), pp. 1637-1642.

Jo, S.H., Ha, K.S., Moon, K.S., Lee, O.H., Jang, H.D., Kwon, Y.I. 2011. In vitro and in vivo anti-hyperglycemic effects of omija (Schizandra chinensis) fruit. International journal of molecular sciences. 12(2), pp.1359-1370.

Karadi, R.V., Shah, A., Parekh, P., Azmi, P. 2011. Antimicrobial activities of Musa paradisiaca and Cocos nucifera. International Journal of Research in Pharmaceutical and Biomedical Sciences. 2(1), pp. 264-267.

Kappel, V.D., Cazarolli, L.H., Pereira, D.F., Postal, B.G., Madoglio, F.A., Buss, Z. da S, Reginatto, F.H., Silva, F..M.B. 2013. Beneficial effects of banana leaves (musa $\mathrm{x}$ paradisiaca) on glucose homeostasis: multiple 
sites of action. Brazilian Journal of Pharmacognosy. 23(4), pp. 706-715.

Maya, S.W., Citraningtyas, G., Lolo, W.A. 2015. Phytochemical screening and antipyretic effect of stem juice from kepok banana (Musa paradisiaca 1 ) on white male rats stain wistar (Rattus norvegicus) induced with DTP-Hb. Pharmacon. 4(1), pp. 1-11.

Pannangpetch, P., Vuttivirojana, A., Kularbkaew, C., Tesana, S., Kongyingyoes, B., Kukongviriyapan, V. 2001. The antiulcerative effect of Thai musa species in rats. Phytotherapy Research. 15, pp. 407-410.

Pattanayak, S., Nayak, S.S., Panda, D., Shende, V. 2009. Hypoglycemic of Cajanus scarabaeoides in glucose overloaded and streptozotocin-induced diabetic rats. Bangladesh Journal of Pharmacology. 4(2), pp. 131-135.

Rathod, N.R., Chitme, H.R., Irchhaiya, R., Chandra, R. 2011. Hypoglycemic effect of Calotropis gigantea linn. Leaves and flowers in streptozotocin-induced diabetic rats. Oman Medical Journal. 26(2), pp.104-108.

Sakamoto, E., Seino, Y., Fukami, A., Mizutani, N., Tsunekawa, S., Ishikawa, K., Ogata,H., Uenishi, E., Kamiya, H., Hamada,Y., Sato, H., Harada, N., Toyoda, Y., Miwa, I., Nakamura, J., Inagaki, N., Oiso, Y., Ozaki, N. 2012. Ingestion of a moderate high-sucrose diet results in glucose intolerance with reduced liver glucokinase activity and impaired glucagon-like peptide-1 secretion. Journal of Diabetes Investigation. 3(5), pp.432-440.

Sofowora, A., Ogunbodede, E., Onayade, A. 2013. The role and place of medicinal plants in the strategies for disease prevention. African Journal of Traditional, Complementary and Alternative Medicines. 10(5), pp.210-229.

Wahyuningsih, D., Purnomo, Y. 2018. Antidiabetic effect of Urena lobata: preliminary study on hexane, ethanolic, and aqueous leaf extracts. Jurnal Kedokteran Brawijaya. 30(1), pp.1-6.
Wongnawa, M., Tohkayomatee, R., Bumrungwong, N., Wongnawa, S. 2014. Alpha-glucosidase inhibitory effect and inorganic constituents of Phyllanthus amarus schum. \& thonn. Ash. Songklanakarin Journal of Science and Technology. 36(5), pp. 541546.

Wulandari. 2016. Uji efektivitas antihiperglikemia kombinasi jus pare (Momordica charantia 1) dan jus tomat (Solanum lycopersicum 1) pada tikus wistar jantan dengan metode toleransi glukosa. Pharmaceutical Sciences and Research.3(3), pp. 145-154.

Yeo, J.Y., Ha, T.J., Nam, J.S., Jung, M.H. 2011. Antidiabetic effects of Vigna nakashimae extract in $\mathrm{Db} / \mathrm{Db}$ mice. Bioscience, Biotechnology and Biochemistry. 75(11), pp. 2223-2238.

Yusoff, N.A., Ahmad, M., Al-Hindi, B., Widyawati, T., Yam, M.F., Mahmud, R., Razzak, K.N.A., Asmawi, M.Z. 2015. Aqueous extract of Nypa fruticans wurmb. Vinegar alleviates postprandial hyperglycemia in normoglycemic rats. Nutrients. 7, pp.70127026 . 